\title{
Development of Web Mapping Application for Spatial Ecotourism Information Using QGIS Plugin and Freely Available Web Platforms in North West Highlands of Ethiopia a Case Study: Chokie Mountain Watersheds
}

\author{
Mengesha Endalew ${ }^{1}$, Wobetu Shiferaw ${ }^{2}$, Abinet Kindie ${ }^{3}$ \\ ${ }^{1}$ Geodesy and Geomatics Engineering, School of Civil and Water Resource Engineering, Institute of Technology, \\ Debre Markos University, Debre Markos, Ethiopia \\ ${ }^{2}$ Software Engineering, School of Computing, Institute of Technology, Debre Markos University, Debre Markos, Ethiopia \\ ${ }^{3}$ Information Technology School of Computing, Bahirdar University, Bahirdar, Ethiopia \\ Email: mengeshaendalew79@gmail.com
}

How to cite this paper: Endalew, M., Shiferaw, W. and Kindie, A. (2019) Development of Web Mapping Application for Spatial Ecotourism Information Using QGIS Plugin and Freely Available Web Platforms in North West Highlands of Ethiopia a Case Study: Chokie Mountain Watersheds. Advances in Internet of Things, 9, 50-61.

https://doi.org/10.4236/ait.2019.93004

Received: May 10, 2019

Accepted: July 28, 2019

Published: July 31, 2019

Copyright $\odot 2019$ by author(s) and Scientific Research Publishing Inc. This work is licensed under the Creative Commons Attribution International License (CC BY 4.0).

http://creativecommons.org/licenses/by/4.0/

\section{(c) (i) Open Access}

\begin{abstract}
Ecotourism is a sustainable, green and smokeless industry of the society by providing alternative source to the livelihood and local community, in order to re-naturalize the environment to bring the man closer to the natural environment. The use of web application has changed the way tourists gather information about tourist attraction spots of the research area. The aim of the study is to assess and identify ecotourism attraction sites of Chokie Mountain watersheds for touristic activities to develop a web-based GIS mapping portal for the improvement of nature-based ecotourism activities. The web-based GIS portal for Web Mapping Application is available for the user with the skills necessary to create standard web mapping services. We have implemented web mapping services based on formal cartographic visualization rules in the open source QGIS software and threejs JavaScript plugin. Threejs plugin is used for $3 \mathrm{D}$ visualization, interaction and export terrain data, map canvas image and vector data to HTML page and JS. The result of web-based GIS portal supports spatial and non-spatial database of tourist attraction and tourist service data with attractive user interface.
\end{abstract}

\section{Keywords}

Ecotourism, Chokie Mountain Watersheds, Spatial Mapping, Qgis, Open Source Software, Qgis2threejs Plugins 


\section{Introduction}

Ethiopia is land of origin with vast number of tourist attractions [1] and a visitor-friendly people [2] who are conscious of its historical, cultural and natural heritages [2] [3] [4]. It was this recognition of a great potential, that the tourism industry has been started in 1960's in the country [5]. Choke Mountain watershed has tourism potentials such as the stunning landscapes like Aba Jime forests, AratMekerakir, Molalit cave, Lake BahireGiyorgies in line with unique biodiversity resources which include plant, animal, and bird species [2]. Ecotourism was first started by the Hetor Ceballos lascurain in 1983 [6]. It includes a number of different forms of tourism such as environmentally responsible nature-based travel, adventure travel, birding or camping and generally, it is a tourist activity for sustainable protection of the environment and generating sustainable income for the local community [6]. Tourism, the act of travel for the purpose [7] of relaxation, physical and mental recovery, responsible travel to natural areas [8] and business, and provide services for the tourist [9]. It is a sustainable [3] [10], nature-based [6] green and smokeless industry [7] of the society by providing sustainable environment [3] and income, good interaction with nature, people and community involvement, and action to conserve or enhance the natural environment, in order to re-naturalize the environment to bring the man closer to the ecotourism area. GIS technology has an essential computer tool for [11] [12] collecting, storing, mapping, analyzing, managing, retrieving and displaying of spatial and attribute data for geographic world of particular purpose. Web GIS is a geographic information system distributed across a networked computer environment to integrate, disseminate, and communicate geographic information visually on the World Wide Web [13]. The study uses free \& open source software to implement web GIS technology for ecological tourism development of Choke Mountain watershed.

\section{Methods}

\section{Study Area}

Chokie Mountain watersheds are the water tower of the upper Blue Nile River Basin [4] [14] (Abay) highland portions of Ethiopia, in West and East Gojjam zonal administrations, Amhara regional state northwest part of Ethiopia. Choke Mountain is the water tower of the Upper Blue Nile River Basin in Ethiopia. It is the source of more than 23 rivers and 273 small springs [2] which are the main tributaries of Upper Blue Nile river basin. The watershed located between $37^{\circ} 00^{\prime} 00^{\prime \prime}$ - 38 $30^{\prime} 00^{\prime \prime E}$ longitude and $9^{\circ} 30^{\prime} 00^{\prime \prime}-11^{\circ} 00^{\prime} \mathrm{N}$ latitude. The latitude of the area ranges from $667 \mathrm{~m}$ around Blue Nile George to $4100 \mathrm{~m}$ top of Chokie Mountain watershed. Agroecologically, Choke Mountain watersheds region (Table 1) is found within four climatic zones. These are; Kola, WeynaDega, Dega, and Wurch [14].

It is the source of more than 273 spring water and many other major rivers in the region. Choke Mountain watersheds, the water tower of the region and its 
Table 1. Climatic zone of Chokie Mountain watersheds [14].

\begin{tabular}{ccccc}
\hline Climatic Zone & Climate & Altitude & Temperature & Avg. ann. Rainfall \\
\hline Bereha & Hot arid & $<500$ & $>27.5$ & $<200$ \\
Kola & Warm semi arid & $500-1500 / 1800$ & $27.5-20$ & $200-800$ \\
WoinaDaga & Cool sub humid & $1500 / 1800-2300 / 2400$ & $20-17.5 / 16$ & $800-1200$ \\
Dega & Cool and humid & $2300 / 2400-3200$ & $17.5 / 16-11.5$ & $1200-2200$ \\
Wurch & Cold and moist & $>3200$ & $<11.5$ & Above 2200
\end{tabular}
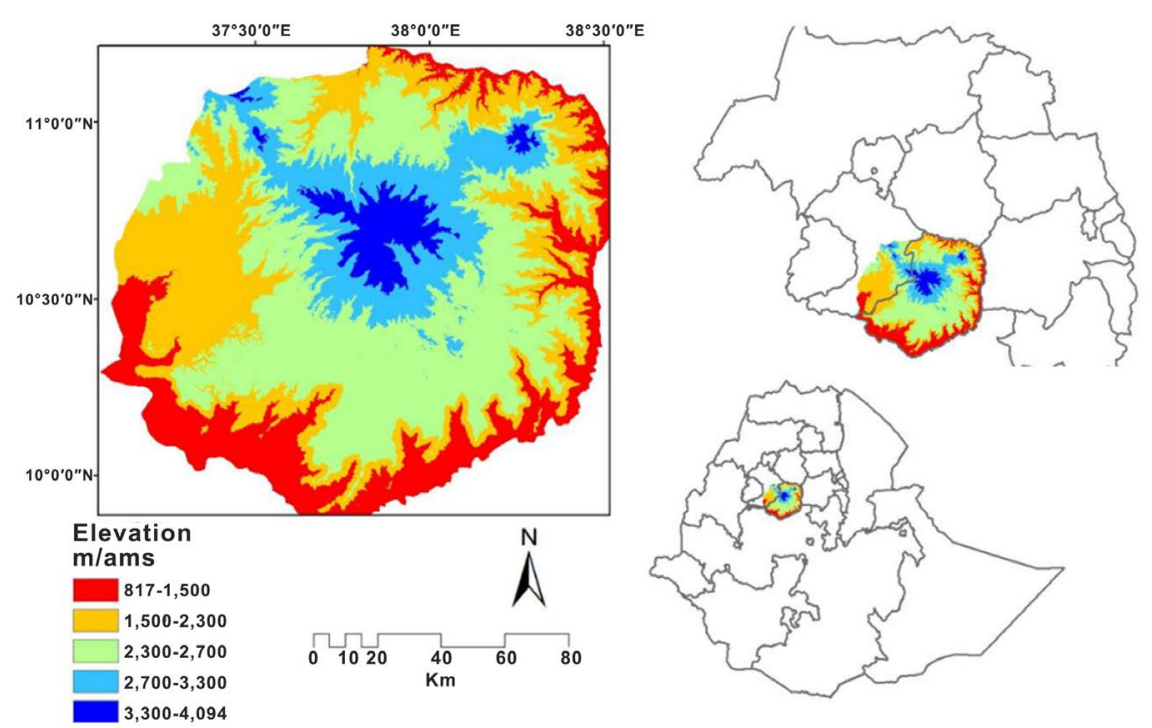

Figure 1. Chokie mountain watersheds.

surroundings (Figure 1) has a nature-based tourism potentials [2] [6] and diverse range of geographic features like landforms, water basin, gorges, cliffs, native biological diversity and other spectacular views. Variation of atmospheric conditions in the watershed such as rainfall, wind, temperature and humidity are the result of natural conservation and its topography. The amazing landscape like Aba Jime forests, Arat Mekerakir, Molalit cave, Lake BahireGiyorgies in line with unique biodiversity resources which include plant, animal, and bird species are big nature-based resources [2] [4]. Like [2] findings, 41 bird species are found in Afro-tropical highland biome of Choke Mountain including endemic Abyssinian Longclaw (Macronyx flavicollis). Some of the bird species [2] are endemic for Ethiopia such as Abyssinian Longclaw, Wattled Ibis, Thick-billed Raven, White-collared Pigeon, and Black-winged Lovebird.

There are 16 animal species [2] [4] found in Choke Mountain and its Environs such as Leopard (Panthera pardus), Golden/Common Jackal (Canis aureus), Common Bush Back (Tragelaphus scriptus), AbyssiniaColobus, Common Duiker, Spotted Hyena (Crocuta crocuta), Anubis Baboon (Papio anubis), Bush Pig (Potamochoerus porcus), and Common Duiker (Sylvicapra grimmia). The area is also home of many afro-alpine and sub-afro-alpine [2] [4] plant species. In Cho- 
kie Mountain Watershed around 85 plant species [4] are found in the area. Mainly, KosheshilSa (Acanthus sennii), Korch (Erythrina brucei), Gimy (Euryops pinifolius), Ashengidye (Kniphofia foliosa), and Gibra (Lobelia rhynchopetalum) are endemic for northwest highlands of Ethiopia.

\section{Data and Methods}

\subsection{Open Source Software for Web-Based GIS}

The Web GIS should be independent of [15] software license cost, anyone is freely licensed to [13] [16] [17] use, copy, study, and edit the software. Open source software minimizes the price of the project and making it [15] independent of software license costs along the time and hence, only free and open source software technologies are used making it sustainable for the local economy [13] [18]. The main advantage of using freely available web-based software includes [9] [13] [15] decreasing software license costs, increasing security and stability, protecting privacy, giving users a chance to control by their own hardware, and made the software available to all users.

\subsubsection{Wamp Server}

WampServer ( $\mathrm{W}=$ windows, $\mathrm{a}=$ apache, $\mathrm{m}=$ mysql, $\mathrm{p}=\mathrm{php})$ is a Web development platform on Windows that allows you to create dynamic Web applications with Apache2, PHP, MySQL and MariaDB. It's a suite of tools and languages necessary to run and interpret web scripts and it's the most suitable web and application server for applications written based on PHP and MySQL.

\subsubsection{Spatial Database Management Tools}

\section{1) Qgis2threejs Plugins}

It is used for 3D visualization, interaction and export terrain data, map canvas image and vector data to HTML page and JS file [19]. 3D visualization based on available spatial data and Three.js library enables user-friendly interactive 3D visualization, which is accessible to a broad spectrum of users and it does not require any new software or plugins to be installed on the client or server sides.

\section{2) Quantum GIS}

QGIS supports import and export of different file formats through the interaction of GDAL OGR libraries, including vector, raster and CAD data formats as Figure 2 given below. It is an open source software with more advanced cartographic features for thematic mapping [16]. The development of Web GIS and Web Mapping Applications with the QGIS MapServer provides the participants

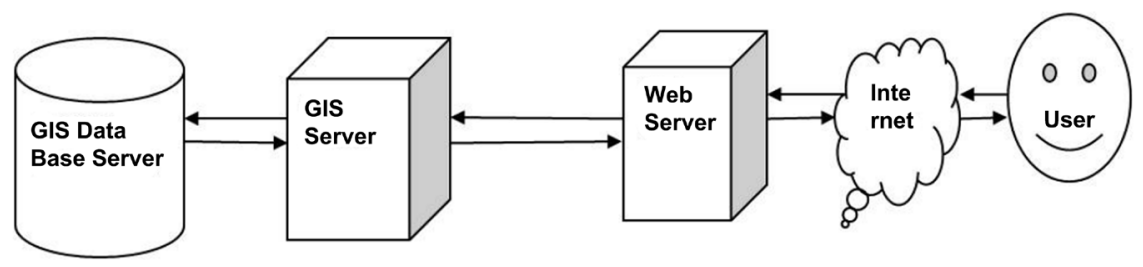

Figure 2. Application architecture for web-based GIS mapping [9] [17]. 
with the skills necessary to create their own standardized Web mapping services based on formal cartographic visualization rules implemented in the open source software QGIS MapServer.

\subsubsection{Front End Web Development Tools}

Our web application is developed based on a 3-tier client-server architecture [20] where the application is separated into 3 layers. i.e. the presentation layer which includes user interface components, the business logic layer which interfaces the presentation with the backend data (database) and the database management layer which includes the persistent data storage system. Different technologies are used to build different layers. Frontend development is all about the development of the presentation layer using client-side technologies. We used HTML, CSS and JavaScript for frontend development.

\section{HTML, CSS and JavaScript}

We used Hypertext Markup Language (HTML) [21] to design the application's organization and content, and Cascading Stylesheet (CSS) (Figure 3) Different web application frameworks available to make these HTML pages have a better look and feel. We used JavaScript which provides user interactivity with the application and is necessary to handle asynchronous communications [22] with the server.

\subsubsection{Backend Web Development}

The backend development includes the development of the business logic layer and this is implemented by server-side scripting languages such as PHP, ASP or JSP. As stated above we chose PHP as a backend development platform.

\section{PHP scripting language}

It is a widely used open source, server side, HTML embedded web scripting language that is compatible with all major web servers (notably with apache2) [23]. Being open source, cross platform, free full-featured and stable forces us to choose as the right backend development tool for our experiment.

\subsubsection{Non-Spatial Database Management Tool}

The web GIS data is known to be managed using spatial and non-spatial data management tools. As stated, we used Postgre and Quantum GIS as spatial data

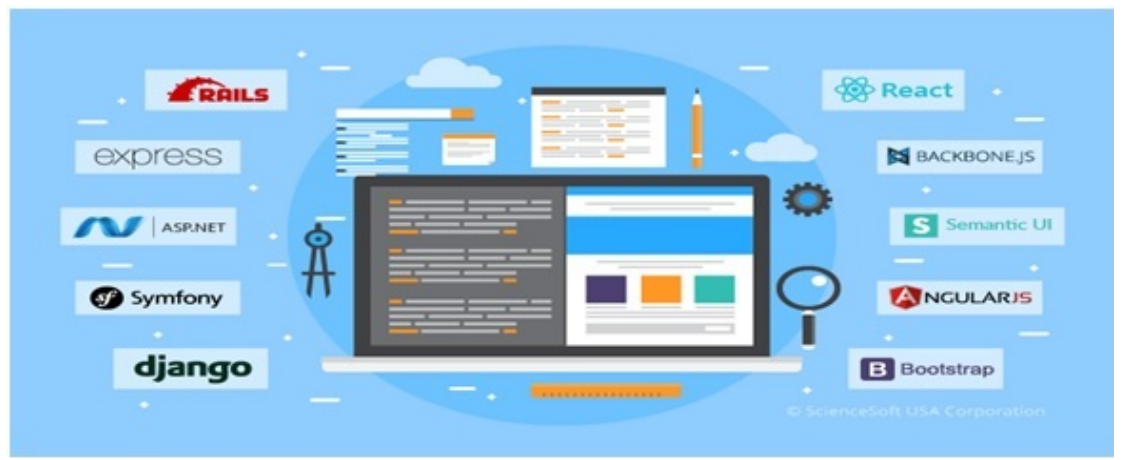

Figure 3. Different web application frameworks are available. 
management tool. For non-spatial data management, we made some comparisons among the most popular relational database management (RDBMS) tools. The most notable ones are MySQL, Microsoft SQL Server, Oracle, etc. and we chose MySQL for our purpose. The main reason behind is it's a suite of software in the WAMP stack and is usually the most widely used persistent storage technology on which PHP based applications work with.

\subsection{Web Development Frameworks and Toolkits}

The main important thing that the Object-Oriented programming methodology is that it allows to write code which is reusable across different projects. So different software companies and developers developed a code based on a certain programming language that can ease software development for others. These codes, known as web frameworks, automate common tasks of development such as architecture, design pattern, security and performance of any software development and help other developers concentrate only on automating the business logic of their project.

A web application framework is a software stack that is designed to support web applications including web services, resources and Application Programming Interfaces (APIs). They provide a standard way to build and deploy web applications. In our experiment, we made use of different frameworks and libraries available for frontend and backend developments. For front-end, we used Bootstrap CSS library (open source toolkit for developing with HTML, CSS and JS) [24] as well as AngularJS (a JavaScript-based open-source front-end web application framework to address many of the challenges encountered in developing single-page applications) [25] [26] JavaScript framework. For backend, we used Laravel PHP framework [27] [28]. We chose this framework based on:

1) The languages we decided as stated above;

2) Their popularity of developer community support as well as;

3) Based on the decision that which one is the latest technology.

\section{Result and Discussion}

\subsection{Web GIS Development}

A web-based GIS is a GIS application made available through a common web browser for [29] easy, fast and cost-effective dissemination, sharing, displaying and processing of spatial information. Together with the use of the World Wide Web, GIS could be further developed to allow many more people to have access to GIS functionality and to enhance community participation in planning. Web-based GIS, an extension of Geographic Information System (GIS), consists of four major system components which include client for [15] sending request through web browser, web server with application server for responding to the request, map server and data server. The above four major web components would be integrated to develop web-based GIS portal for choke mountain watershed. Web-based GIS is being one of the newest fields in Geographic Infor- 
mation systems for web-based map creation using different commercial, open source and public software and technologies. Open source software system is developing rapidly with the involvement of a large number of people and can be used free of charge by having poor documentation.

Web GIS is the process of [15] designing, implementing, generating and delivering maps on the World Wide Web by combining both the advantage of GIS and the internet. GIS-based project development consists of components such as [13] data development, data organization, and application development that are not similar and different from the standard software development processes. The major components of web application portal are categorised [9] [11] [15] [29] into navigation tools (zoom in, zoom out, zoom to full extent, selective zoom, re-centre tool, linear measuring tools), legend tools, search tools and print map tools.

\subsection{Architecture and Implementation}

The web application architecture in Figure 4 User side web services [30] shown below represents [9] [17] [30] the data communication link between the web service and various components.

Free and open source application platforms for [29] publishing spatial data (vector and raster data format) and interactive mapping application using QGIS freely available web-based plugin to the web have been [29] used as spatial data server.

\subsection{The Web GIS Web Portal Prototype}

We have developed a prototype web portal application based on the specifica

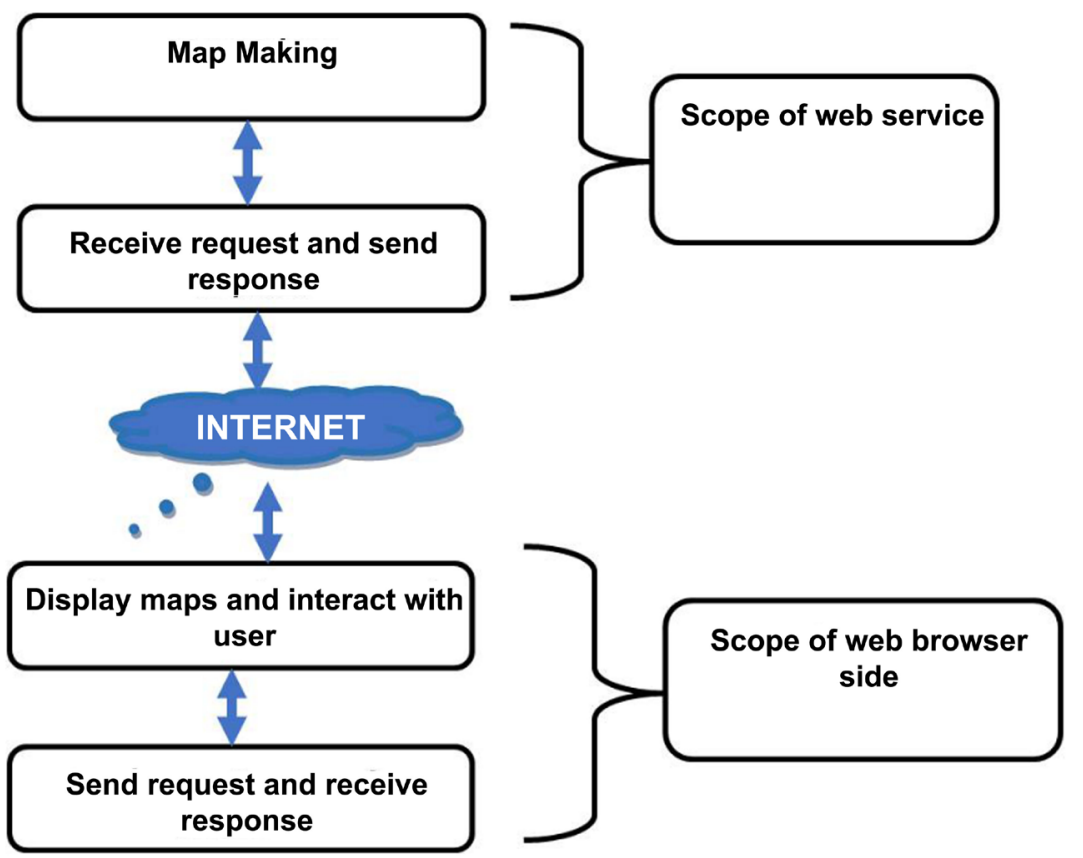

Figure 4. User side web services [30]. 


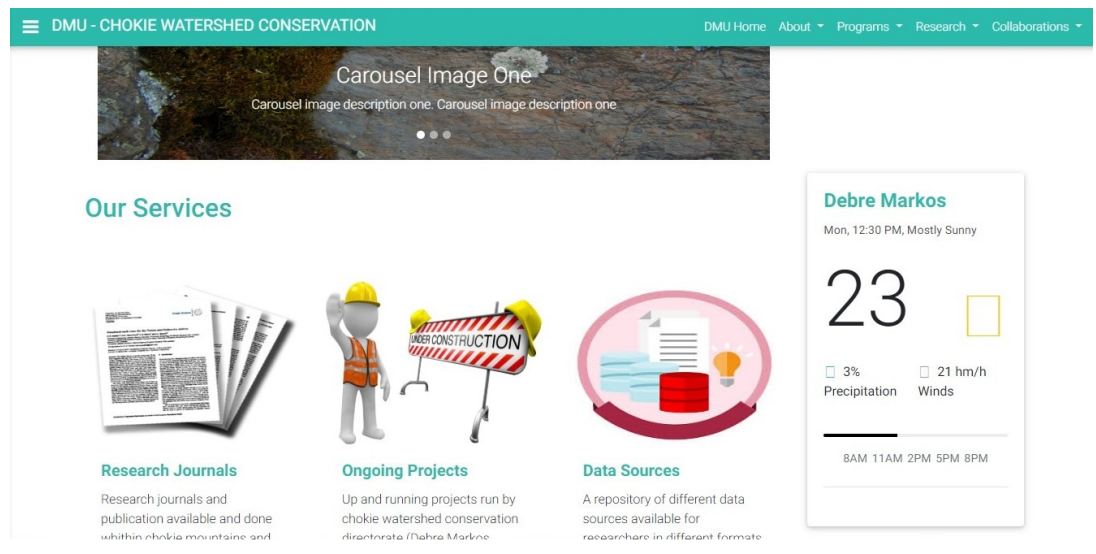

Figure 5. Home pages of Chokie mountain watersheds.

tions defined in the above sections of this paper. The web application is entitledas "Chokie Mountains Watershed Conservation" and provides main services such as Geo-spacial information about the study area, general and background information, research and project publication database, web services and data sources about the study area for other researchers and publishes daily activities going on related to the study area. Since the area has immense capability for research and development, frequent information delivery is very important.

\subsubsection{Home Page}

The application currently is running on local development server on WAMP server installation. Since we are developing the portal app based on the laravel framework, it runs on laravel local development server on top of wamp. The researcher tries to activate the server from composer command line interface as "php artisan serve" and the server starts server with http://localhost:8000 default address. The home page is shown in Figure 5.

The home page contains information such as a showcase to display informative pictures, top menu which contain home, about, programs, research and collaboration menu items to detail information related to the different programs run by Debre Markos University chokie Mountains Conservation Directorate office such as research and technology transfer, community development, thematic areas, publications and running projects and external relations.

The front page contains sections such as "our services" that advocate the services provided by the portal and "In the News" that broadcast frequent activities done by stakeholders.

\subsubsection{Side Menu}

The side menu, located at the right of the showcase, contains menu items to display information about media galleries, google map location of the study area and a link to the Web GIS map of the study area. The portal displays much other important information such as the daily weather condition of the site

\section{Conclusions}

Ecotourism is a sustainable, green and smokeless industry of the society by pro- 
viding alternative source to the livelihood and local community in order to re-naturalize the environment. Choke Mountain watersheds have [4] ecological tourism potential sites such as the stunning landscapes like Aba Jime forests, Arat Mekerakir, Molalit cave and Lake Bahire Giyorgies in line with unique biodiversity resources which include plant, animal, and bird species. The use of web mapping application changes the way tourists gather information about nature-based tourist attraction spots of the research area. we have been used free and open source application platforms as spatial data server for publishing spatial data and interactive mapping application using QGIS freely available web-based plug-in. Open source web application software's are very easy and powerful tool to delineate, conserve and promote ecotourism areas for sustainable, smokeless and green industry of the country. Chokie Mountain watershed conservation web portal provides Geo-spatial information about the study area, General and background information, Research and project publication database, Web services and data sources for other researchers and publishes daily activities going on related to the study area.

\section{Acknowledgements}

This research work Grand was funded by Debre Markos University (Ethiopia) research and community service office.

\section{Conflicts of Interest}

The authors declare no conflicts of interest regarding the publication of this paper.

\section{References}

[1] Sefrin, C. and Bohle, H.-G. (2012) Ecotourism in Lake Tana Region, Ethiopia-Potential for the Implementation of Community-Based Ecotourism. Geogr. institutes der Rheinische Friedrich-Wilhelms-University Boon. http://www.succow-stiftung.de/tl_files/pdfs_downloads/Diplomarbeiten/2012Diplo marbeitOekotourismus\%20Tanasee\%20Christian\%20Sefrin.pdf

[2] Hospit, J.T. and Aseres, S.A. (2015) Assessment of the Potentials Tourism Resources of Choke Mountain and Its Environs, Ethiopia. Journal of Tourism \& Hospitality, 4, 164.

[3] Kiper, T. (2013) Role of Ecotourism in Sustainable Development. In: Advances in Landscape Architecture, IntechOpen, London, 773-802. https://doi.org/10.5772/55749

[4] Robe, B. and Ababa, A. (2016) Development of Community-Based Ecotourism, a Case of Choke Mountain and Its Environs, Ethiopia. Challenges and Opportunities, $16,14-21$

[5] Rahman, A. (2010) Application of GIS in Ecotourism Development: A Case Study in Sundarbans, Bangladesh. Master's Thesis, Mid-Sweden University, Sweden.

[6] Guan, H.-L., Luo, Y.-P. and Wu, L.-Q. (2011) A GIS-Based Approach for Information Management in Ecotourism Region. Procedia Engineering, 15, 1988-1992. https://doi.org/10.1016/j.proeng.2011.08.371 
[7] Cheia, G. (2001) Ecotourism: Definition and Concepts. Revista de turism-studii si cercetari in turism, No. 15, 56-60.

[8] Vrujci, B. (2005) What Is Ecotourism?-An Introduction. CEEWEB Academy, Ecological Tourism in Europe.

[9] Zerihun, M.E. (2017) Web Based GIS for Tourism Development Using Effective Free and Open Source Software Case Study: Gondor Town and Its Surrounding Area, Ethiopia. Journal of Geographic Information System, 9, 47-58. https://doi.org/10.4236/jgis.2017.91004

[10] Nino, K., Mamo, Y., Mengesha, G. and Kibret, K.S. (2017) GIS Based Ecotourism Potential Assessment in Munessa Shashemene Concession Forest and Its Surrounding Area, Ethiopia. Applied Geography, 82, 48-58.

https://doi.org/10.1016/j.apgeog.2017.02.010

[11] Zhang, J.Z., Zhu, Y., Wang, J., Sun, J. and Xu, Y. (2011) Flash Based WebGIS System and Its Application in Monitoring and Evaluating China's Regional Development. International Journal of Digital Content Technology and Its Applications, 5, 285-295.

[12] Akukwe, T.I. and Odum, C.J. (2014) Designing and Developing a GIS Database for Tourism in Nigeria: The Case of Anambra State. IOSR Journal of Humanities and Social Science, 19, 109-120. https://doi.org/10.9790/0837-19108109120

[13] Markos, A. (2014) Research in Social Science the Role of "Web GIS " in the Development of Tourism-In the Case of Bahir Dar Town and Its Surroundings, Amhara Region, Ethiopia. Journal of Radix International E, 3, 1-16.

[14] Simane, B., Zaitchik, B.F. and Ozdogan, M. (2013) Agroecosystem Analysis of the Choke Mountain Watersheds, Ethiopia. Sustainability, 5, 592-616. https://doi.org/10.3390/su5020592

[15] Agrawal, S. and Gupta, R.D. (2014) Development and Comparison of Open Source based Web GIS Frameworks on WAMP and Apache Tomcat Web Servers. The International Archives of the Photogrammetry, Remote Sensing and Spatial Information Sciences, XL-4, 1-5. https://doi.org/10.5194/isprsarchives-XL-4-1-2014

[16] Iosifescu, I. (2010) GIScience 2010 Tutorial Development of Web GIS and Web Mapping Applications with QGIS Mapserver. Quantum, No. 9, 1-19.

[17] Delipetrev, B., Jonoski, A. and Solomatine, D.P. (2014) Development of a Web Application for Water Resources Based on Open Source Software. Computers \& Geosciences, 62, 35-42. https://doi.org/10.1016/j.cageo.2013.09.012

[18] Belay, A. (2005) Internet-GIS: An Application to Real Estate and Housing Management in the City Government of Addis Ababa (CGAA). Addis Ababa University, Ethiopia.

[19] Herman, L., Russnák, J. and Řezník, T. (2017) Flood Modelling and Visualizations of Floods through 3D Open Data Open Data. In: Hřebíček, J., Denzer, R., Schimak, G. and Pitner, T., Eds., Environmental Software Systems. Computer Science for Environmental Protection. IFIP Advances in Information and Communication Technology, Springer, Cham, 1-13.

[20] Client-Server Architecture. https://www.britannica.com/technology/client-server-architecture

[21] Client-Side Scripting and HTML. https://www.w3.org/TR/WD-script-970314

[22] What Is Asynchronous Data? https://www.techopedia.com/definition/26893/asynchronous-data

[23] Converse, T., Park, J. and Morgan, C. (2004) PHP5 and MySQL Bible. Wiley, Ho- 
boken, NJ.

[24] The Health Informatics Service (2018) Bootstrap-The Most Popular HTML, CSS, and JS Library in the World.

[25] Green, B. and Seshadri, S. (2013) AngularJS. O’Reilly Media, Sebastopol, CA.

[26] Angular. https://angular.io/

[27] Bean, M. (2015) Laravel 5 Essentials: Explore the Fundamentals of Laravel, One of the Most Expressive and Robust PHP Frameworks Available.

[28] Laravel-The PHP Framework For Web Artisans. https://laravel.com/

[29] Singh, P.S., Chutia, D. and Sudhakar, S. (2012) Development of a Web Based GIS Application for Spatial Natural Resources Information System Using Effective Open Source Software and Standards. Journal of Geographic Information System, 4, 261-266. https://doi.org/10.4236/jgis.2012.43031

[30] Fu, P. and Sun, J. (2012) Web GIS: Principles and Applications. Esri Press, Redlands, CA, 1-37.

\section{Screenshoots of Computor Programs}

\section{Web Gis Controller the controller class file}

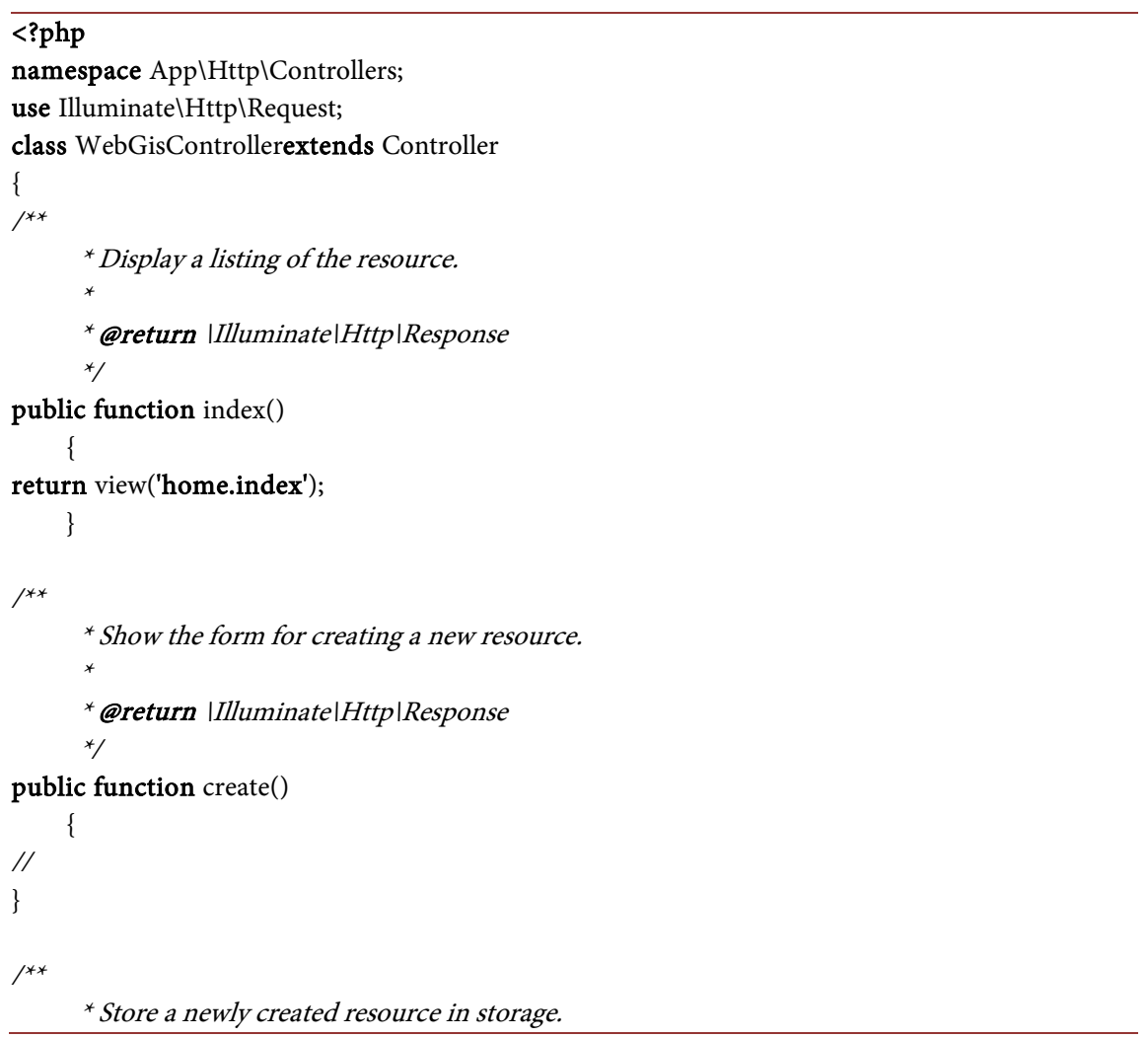




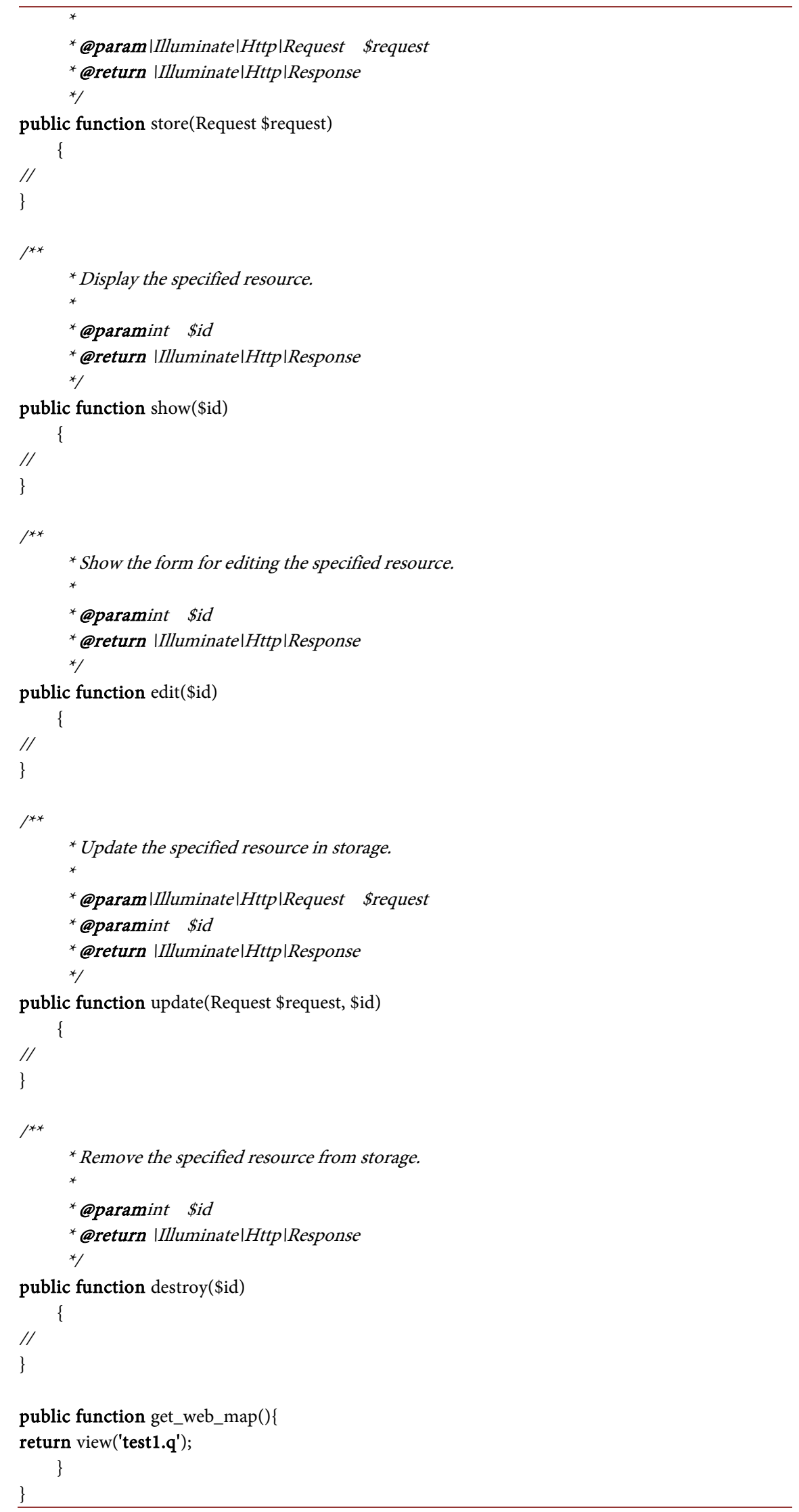

